\title{
Ranching Sustainability in the Northern Great Plains: An Appraisal of Local Perspectives
}

\section{Authors: Julia Hobson Haggerty, Mason Auger, and Kathleen Epstein}

NOTICE: this is the author's version of a work that was accepted for publication in Rangelands. Changes resulting from the publishing process, such as peer review, editing, corrections, structural formatting, and other quality control mechanisms may not be reflected in this document. Changes may have been made to this work since it was submitted for publication. A definitive version was subsequently published in Rangelands, VOL\# 40, ISSUE\# 3, (June 2018) DOI\#10.1016/j.rala.2018.03.005.

Haggerty, Julia Hobson, Mason Auger, and Kathleen Epstein. "Ranching Sustainability in the Northern Great Plains: An Appraisal of Local Perspectives." Rangelands 40, no. 3 (June 2018): 83-91. DOI:10.1016/j.rala.2018.03.005. 


\section{Ranching Sustainability in the Northern Great Plains: An Appraisal of Local Perspectives}

\section{By Julia H. Haggerty, Mason Auger, and Kathleen Epstein}

\section{On the Ground}

- In eight counties in Montana, South Dakota, and Nebraska characterized by high levels of intact Northern Great Plains grassland habitat, ranchers observe the following sustainability challenges:

- Land prices and lack of land for purchase

- Profitability

- Family succession and community change (depopulation)

- Notably, they do not anticipate extensive cropland conversion in the western edge of the Northern Great Plains.

-We observed differences in the experience of these challenges based on the ranch ownership lifecycle.

- In response, we recommend that conservation and government programs focused on sustainable ranching should adopt a framework for strategy and program evaluated based on the lifecycle framework.

- Assisting emerging ranchers, according to this research effort, will demand more than coming up with loan funds or extra forage. Rather it will mean rethinking the existing pathway that operators follow on the route from emerging to established ranchers.

- In addition, conservation and government programs and future research should address the impacts and patterns of land agglomeration in the Northern Great Plains. panning 183 million acres, five states (North Dakota, South Dakota, Nebraska, Montana, and Wyoming) and two Canadian provinces (Alberta and Saskatchewan), the Northern Great Plains (NGP), a short- and mixedgrass prairie, is one of only four remaining intact temperate grasslands in the world. ${ }^{1}$ Roughly half of the 183 million acres in the NGP (or 91 million acres) are privately managed intact rangelands (e.g., native and planted grass, sage steppe), primarily used for beef production. These private ranches provide habitat for threatened species and contribute to ecosystem service provision such as carbon sequestration and water quality and quantity. From this perspective, native prairie represents one of North America's greatest assets and most important conservation opportunities, and ranchers are managing much of what remains today.

In recent years, diverse forces have converged to accelerate land use and social change in the grasslands of the NGP, including the spatial expansion of soy and corn crop agriculture and fossil fuel energy development, as well as land ownership transfers involving buyers new to the ranching landscape. The pace and scale of changes resulting from these forces, along with continued and growing concern about the vulnerability of the region to the impacts of climate change, have prompted global and national interest in developing conservation strategies that align with the region's unique social, economic, and environmental qualities. As a step in the development of targeted conservation strategies, we recently conducted an appraisal of current trends in ranch ownership and management in NGP. Our appraisal relied on a combination of land ownership data, socioeconomic data, and in-depth interviews with ranch operators and other local and regional experts. A full-length report, available online, offers socioeconomic trend data, results of an exploratory land tenure analysis, and supplemental maps. ${ }^{2}$

In this article, we share what we learned from interviewing 56 ranchers and other local agricultural experts about the nature of perceived threats and opportunities to the sustainability of their grassland operations. We aim to continue the shared dialogue that has recently emerged between diverse stakeholder groups in the region including ranchers, nongovernmental organizations (NGOs), land management agencies, and community development professionals. Along with the results of our interviews, we offer a new framework for thinking about sustainability challenges and their interventions: the ranch lifecycle framework.

\section{A Classic, yet Vulnerable, Grasslands Geography}

Figure 1 describes the importance of the Northern Great Plains to the future of grasslands conservation, which shows intact prairie habitats by ownership type. The western edge of the NGP, 


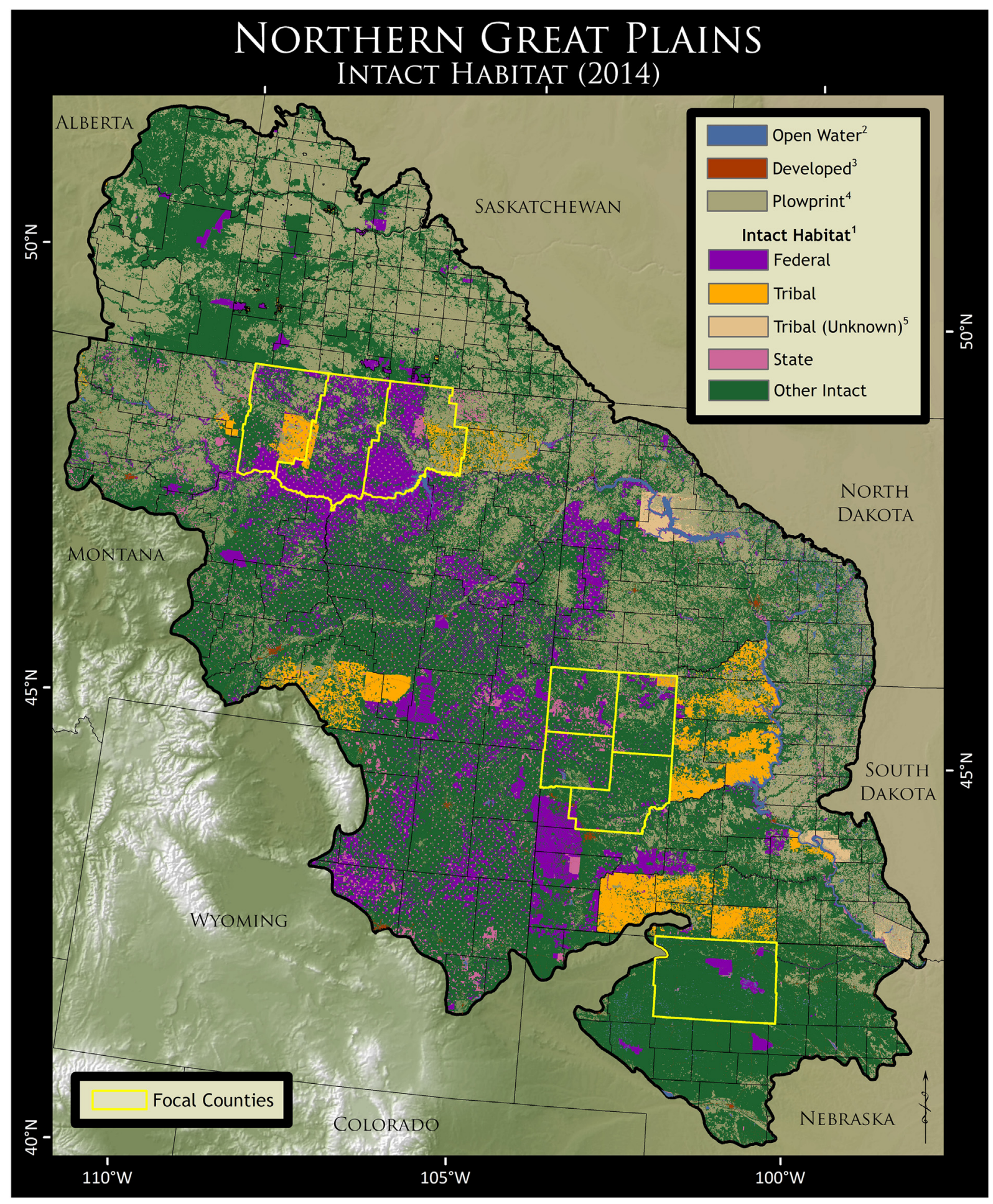

Figure 1. Northern Great Plains, intact habitat and study area. Map by Sarah Olimb, World Wildlife Fund. Intact habitat, as defined by the 2016 World Wildlife Fund Plowprint Report (available online at https://www.worldwildlife.org/projects/plowprint-report), includes those lands that were not in annual crops as of 2008 (in the United States) or 2009 (Canada) and have not been converted to annual crops between 2008 and 2009 and 2016 (or the most recent year of data), and are also not classified as developed, barren, or open water as of 2011 (the most recent data available for these categories). Intact habitat may include: lands that were converted and planted back to grass prior to 2008-2009 (through conservation programs such as Conservation Reserve Program or other private land management decisions); lands that have not been converted since 2008/9 but are not in native cover; lands that have a mix of native and non-native vegetation and are managed to a variety of standards; and lands that have pristine, native cover.

where soil quality and the lack of irrigation supplies have limited the incursion of crop agriculture, stands out as a vital landscape for the ecosystem functions dependent on intact grasslands. While literature suggests that these particular locations make important conservation targets due to their potential for conversion under certain market and policy conditions, ${ }^{3}$ the character and implications of land use and land tenure change at the arid, western edge of the NGP remain largely unexamined. Our 
interviews focused on eight counties where large, intact grassland ranches exist beyond the edge of cropland agricultural zones, specifically Cherry County, Nebraska; Butte, Harding, Perkins, and Meade counties in South Dakota; and Blaine, Phillips, and Valley counties in Montana.

\section{Pressures on NGP Ranch Operations and Current Conservation Approaches}

The NGP region presents an array of well-documented environmental and market challenges for ranchers. Two challenges that have recently emerged as critical concerns center on competition for land (from both crop agriculture and investment) and amenity interests. These challenges intersect with perennial issues in ranching, including the relationship between volatile commodity prices, weather (including climate change impacts), profitability, and the challenges of intergenerational succession.

Strategies in contemporary grassland conservation reflect two distinct approaches to the problems facing ranch sustainability. The first focuses on outright acquisition of land or easements as vehicles to ensure conservation practice on grasslands. ${ }^{4}$ There are variable outcomes for the social composition of ranching communities: easements can help ranching operations by providing an infusion of cash or lowering tax burdens, while land acquisitions result in the agglomeration of conservation properties and the loss of resident ranch operators.

The second suite of strategies targets existing ranching operations as vehicles for grassland sustainability and conservation. ${ }^{5}$ In this category are programs that build capacity of local stewardship organizations, various efforts to disseminate best management strategies through the public sector, grass banking, ${ }^{6}$ conservation credits for wildlife habitat protection, ${ }^{7}$ and financial support through low interest federal loan programs. As ranch succession has become a key concern, programs have emerged to enhance landowner to landowner networks to enable transfer of agricultural properties to other operators. With so much variety in the strategies and actors engaged in ranching sustainability - and the recent acceleration in forces of change (e.g., climate change impacts, cropland conversion, and investment-driven land acquisition) - it makes sense to undertake a broad scan of the landscape with the goal of understanding how local actors perceive major challenges and what this means for building effective conservation strategies in the future.

\section{Going to the Experts}

Given the importance of current and future ranchland dynamics on the western edge of the NGP, we set out to understand four related questions: 1) What is the range of ranching operational strategies in the study area? 2) What constraints and opportunities are most significant to ranchers with regard to the resilience of their operations? 3) How does the nature of threat and opportunity differ for distinct types of ranch operations in the NGP region? And last, 4) What are the corresponding implications for conservation strategies on the part of NGOs and land management agencies? This article discusses what we learned about the latter three questions.
Table 1. Description of farmer/rancher interview participants by geography and operator type

\begin{tabular}{|c|c|c|c|}
\hline Geographies & MT & SD & NE \\
\hline \multicolumn{4}{|l|}{ Operational type } \\
\hline $\begin{array}{l}\text { Full-time owner-operator farm } \\
\text { or ranch }\end{array}$ & 3 & 9 & 7 \\
\hline $\begin{array}{l}\text { Full-time owner-operator farm } \\
\text { or ranch combining livestock } \\
\text { and cash grains }\end{array}$ & 2 & 1 & 0 \\
\hline Young farm or ranch operator ${ }^{1}$ & 7 & 2 & 3 \\
\hline \multicolumn{4}{|c|}{$\begin{array}{l}\text { MT indicates Montana; NE, Nebraska; and SD, South Dakota. } \\
1 \text { Young farm or ranch operator with } 5 \text { or fewer years of experience } \\
\text { as proprietors of their own operation. We distinguish this category to } \\
\text { indicate the attention paid to including the perspective of established } \\
\text { as well as emerging agricultural operators in our sample. }\end{array}$} \\
\hline
\end{tabular}

Between November 2015 and March 2016, we conducted 56 unique in-person interviews with 34 farm and ranch operators and 22 local and regional experts including academics and representatives of government agencies such as the National Resources Conservation Service (NRCS), USDA Extension, and Farm Services Agency (FSA). We selected rancher and farmer participants purposively based on a range of criteria we derived from the literature and preliminary research. We attempted to obtain a range of participants in terms of geography/location, operational size, operational focus, tenure, and age cohort in the focal areas. Table 1 summarizes the number, geography, and type of operators we interviewed.

A "snowball" methodology allowed us to build from initial participants to identify additional interviewees and was essential to gain access to private participants in remote rural communities. ${ }^{8}$ While snowballing can bias sampling because it depends on the social networks of local participants, we specifically asked for references that could provide a range of perspectives on the questions in our study. We continued to recruit study participants until we reached a level of conceptual saturation, where no new information was gleaned from additional participants.

In a semistructured interview approach, we used an interview guide organized into themes of inquiry informed by the literature, but intentionally left open-ended and flexible in order to tailor lines of questioning that were most relevant to the knowledge and experiences of the given operator. Interview times ranged from 1 hour to 5 hours, lasting between 2 and 3 hours on average. Transcripts were coded for emergent and dominant themes and patterns following a grounded theory approach, ${ }^{9}$ a qualitative data analysis method in which researchers group organize data into conceptual categories through iterative rounds of coding.

Four primary themes emerged from the research: land prices, profitability, succession-related issues, and public perceptions of ranching. While each theme represents a distinct phenomenon it is important to note that they are dynamic, frequently interrelated, and have differential effects on individual operations, depending on a host of other factors such as operation size, local 
geography, water access, available land base, and operation capital/debt ratios to name a few.

\section{How Do Ranchers Perceive the Future of Grasslands Ranching in the NGP?}

Interviews with operators and agricultural professionals suggested confidence in the future of viability of ranching and private ranch management in the western edge of the NGP where grasslands remain largely intact. Barring eventualities such as dramatic market fluctuations, severe and prolonged drought, or the implementation of government regulations that put access to public land grazing wholly out of reach, few established operators expressed any particular or concrete concerns when queried about the future sustainability of their operation. This does negate the challenges confronting the future of ranching and private stewardship of grassland in the NGP, however. And emerging and smaller established operators were less sanguine about future sustainability. Below we consider the primary factors that shape future sustainability challenges for grassland stewardship in the NGP.

\section{Land Prices}

According to interviews, the most noticeable dynamic affecting ranch sustainability across the NGP is the steady, and sometimes steep, rise in the price of private rangeland. A 2015 report $^{10}$ produced by South Dakota State University's extension service shows an approximate $47 \%$ increase in the average reported value of native rangeland from 2010 through 2015 in the core South Dakota counties of this study. The average reported value of pastureland increased by approximately $58 \%$ during the same period. This partially corroborates the consistent claim made by informants across that NGP that ranchland value has increased anywhere from 30-60\% from 2005-2015.

A theme that emerged in interviews with stakeholders was the effects of nonlocal investment on local land market values, but this tended to vary geographically. For instance, in Cherry County, Nebraska, Phillips County, Montana, and Butte and Meade Counties, South Dakota interviewees argued that nonlocal investment capital targeting the amenity and conservation value of large grassland properties was a primary factor in the rise of land sale prices. Competition from amenity investment and exurban expansion along the I-90 corridor connecting Rapid City, Sturgis, and Spearfish appears acute. Ranchers with operations in this area of South Dakota all reported significant increases in land prices from 2005-2015. Interviewees in Harding County, South Dakota and Blaine and Valley Counties Montana, noted little amenity or investment activity in their local geographies. Interviews suggested that agricultural investment and farm operators migrating from eastern South Dakota have been a major factor driving up land prices from 2005 to 2015 in southern Butte and eastern Meade Counties, South Dakota. In geographies where crop farming and ranching overlap, such as the northern tier of Blaine and Valley Counties, Montana and portions of Butte, Meade, and Perkins Counties, South Dakota, interviewees highlighted the potential financial incentives of organic crop conversion as a competitive factor.

The outcomes associated with rising land prices and agglomeration appear to be a mixed bag for NGP ranching according to our interviews. Interviewees suggested that land price acts as barrier to entry for young and emerging ranchers, and agglomeration will lead to less land inventory overall. In contrast, continuing increase in land valuation can provide established ranchers financial security into the future. Yet this dynamic can also generate uncertainty around the eventual disposition of the land. Interviewees noted that even wellestablished mid-sized operations (4,000-8,000 acres) are potentially vulnerable. High prices can incentivize the landowner or heirs to sell all or part of the land to the highest bidder, who may or may not manage the land for cattle production. Such changes in ownership and land use create uncertainty for the future conservation of privately managed grasslands. Large and established ranches are likely well-positioned to benefit, expand, and possibly diversify, according to interviewees. However, it is possible the growth and expansion of the largest operations may prove detrimental to the overall viability of ranching communities in the NGP. This will be discussed in greater detail below.

Another significant factor affecting operators across the NGP is the price and availability of leases. A majority of operators interviewed for this research either lease ground from another landowner or lease some portion of their own land to another operator. Many do both and some emerging ranchers run cattle entirely on leases. Interviewees reported that the cost of leases has increased noticeably over the last 5 years (2010-2015) along with competition for access. Smaller operations and those who operate only on leased ground are most vulnerable if prices continue to rise.

\section{Profitability}

Profitability is a significant constraint on the viability of individual operations. Cost of land (purchase or lease price), capital/infrastructure costs, and input costs can easily overwhelm operation income, a problem that can turn catastrophic when it occurs in consecutive years. In theory, making more capital available to borrow should minimize financial risk or increase opportunities for profitability. However, in our interviews, financing as a sustainability intervention appeared to be relevant primarily to emerging new ranchers, who noted that loans acquired either through FSA programs or private lenders were indispensable, but only as an initial foothold on the trek to viability. As FSA and private lending officers reported, despite availability of relatively affordable loans and financing, the total available loan amounts are rarely if ever enough to secure a viable, income-producing operation on their own. Thus, even with the expansion of loans, the profitability issues tied to land and operating costs outpacing returns may persist over the lifecycle of a ranching operation. Interviews also revealed that financing for established, profitable operations, especially large operations with significant equity, is easily accessed. Thus, in locations where land prices are rising, marginal, beginning, and smaller 
operations are competitively disadvantaged and conditions for agglomeration are potentially significant.

Another emergent interview theme was the diverse ways financial tools interact with the type and size of operations. For example, crop insurance and subsidies can significantly smooth out volatility in farm profits. This in turn contributes to the ability of farmers to outbid ranchers for land in areas where soil type, water access, and irrigation infrastructure make crop production viable. In addition, subsidy and insurance payments are typically made on a per acre basis, and as a result have greatest cash value to large, established operations. Informants who discussed this issue suggested that a more equitable balance of federal compensation and support not only between cattle producers and crop producers, but also between larger, wellestablished ranching operations and smaller, less secure operations could address some of the uncertainty presently confronting private-land ranching in the NGP. ${ }^{11}$

\section{Ranching Communities: Bridging Past and Future}

The dynamics of successfully transferring private ranchland and ranching operations to the next generation poses consistent challenges to ranch sustainability. These challenges, and whether they can be managed successfully or not, have consequences for individual families, the small, often isolated communities of which they are part, and the future of conservation of NGP grasslands.

Ownership transition draws together myriad, often conflicting forces. Economic, social, financial, and familial dynamics all influence whether and how a particular ranch is transferred to the next generation. ${ }^{12}$ This became clear when we queried a rancher about what makes succession issues so vexed. He characterized it this way: "Succession is a point problem for a lot of other associated problems that people maybe have ignored. When the disposition of property becomes the issue a lot of other problems can come to the surface."

Emerging ranchers consistently discussed several issues tied to transition that can act as barriers to establishing viable operations. They argued that older ranchers are frequently unwilling to retire and transition the ranch to a new owner. This can leave emerging ranchers in career limbo into their 30s and even 40s, unsure whether to give up and move in a different direction or continue waiting in the hope that part or all of an operation will become available to them. Besides being unwilling to retire, younger operators noted that older ranchers were sometimes just as unwilling to relinquish operational decision-making, which created tensions in the day-to-day management of the ranch and, occasionally, led to younger ranchers leaving the operation.

The subset of younger ranchers running profitable operations in our interview cohort were emphatic that thoughtful planning on the part of the previous generation - along with a desire to see the operation continue into the future- was the key factor in their viability. When asked what made for a successful transition of ownership, an agricultural professional who works intimately with ranchers on finance and profitability issues said flatly: "When mom and dad want to do it." The meaning of the preceding quotation becomes richer and more ambivalent in light of other key factors. Interviewees reported delays in transition decision-making related to the complexity of balancing equitable distribution of operation and asset values among multiple inheritors, heirs unwilling to transition into ownership and management of the operation, and inadequate retirement planning. Moreover, in areas where increases in land price are correlated with amenity, conservation, agricultural, and other types of investment the incentive to extract the maximum cash value from the property by simply selling to the highest bidder can be significant, especially when coupled with some or all of the factors noted above.

Informants in our study also expressed concern for the future of their small communities if the trend of large operation expansion continues. Old and young across the NGP, but notably in Cherry County, Nebraska, Valley County, Montana, and northern Perkins County, South Dakota worried about the aging demographics and decreasing populations of their small communities. Informants connected these trends with agglomeration and associated dynamics. As land ownership concentrates and the number of operators decrease the likelihood of reversing those trends dims. And beyond the uncertainty of acquiring land and securing a livelihood from ranching, emerging operators with families also worried about the future availability of basic community services. Several young families in remote northern Valley County predicted the local $\mathrm{K}-12$ school will close in the next few years due to decreasing enrollment. If it closes this will entail up to a 75-mile commute, one way, to the nearest available school.

\section{Agglomeration not Conversion}

In our interview data, crop conversion as a serious threat within the focal areas of this study was a less dominant theme. This finding should be interpreted in light of the specificity and variability of local geographies in this study. For example, when considering Harding and northern Butte Counties, South Dakota interviewees reported the threat of grassland conversion to crops as nil due to poor soils and the paucity of accessible water sources. Interviewees considering Blaine and Valley Counties, Montana and northern Meade County, South Dakota readily admitted a degree of threat from conversion. However, in geographies where the potential for crop conversion was acknowledged informants also noted a consistent, long-term history of area crop production. In some locations informants claimed that crop production predated ranching. This was indicative of the perception that some measure of transition from farming to rangeland and vice versa has been historically common. Interviewees claimed that transitional zones characterized by marginal soils and patchy or investment-intensive water access (limited areas of Cherry County, Nebraska, northern Phillips County, Montana, central Butte and Meade Counties, South Dakota) experienced conversion risk in periods when market and regulatory forces incentivized speculative agricultural investment. Operators, extension agents, and other agricultural experts indicated that such dynamics were clearly visible in central Butte County, South Dakota from approximately 2005 to 2012. Beyond factors associated with local geography and broad historical cycles of agricultural production, 
Table 2. The Ranch Ownership Cycle as Operator Typology

Emerging primarily young and/or beginning operators; have transitioned into an existing operation of any size or are working to establish one; typically lease land and/or cattle; may own or have inherited a land base; are often, though not always, financially marginal, lacking capital and equity, have limited cash flow, and some access to financing; may have relatively few operational options

Established operations are generally viable and financially secure with an adequate or more than adequate land base and/or the means to lease or purchase land as needed; typically have steady cash flow, equity, and secure access to financing; have more operational options

Transitioning operations on the verge of transition or retirement; may or may not have a transition plan in place; land, capital, assets may or may not be enough to execute transition plan as desired; operational options are variable though usually more limited than established operations and less limited than emerging operations

the operators we interviewed tended to situate the risk of conversion within a more general category of perceived threats to their particular operation. That is, they tended to characterize the threat posed by conversion as no different or more severe than others (e.g., high land values, increased competition for land base, market volatility, and so on).

Moreover, our study suggests that the overwhelming issue demanding both action and research in the western edge of the NGP region is the agglomeration effects of recent ranch real estate trends. A plausible scenario informed by this research suggests that if land prices continue to rise the inability of small and mid-size operations to competitively bid for land and leases will constrain opportunities for operational expansion or diversification and increase the likelihood of being bought out by larger operations. Presuming larger operations manage the land well this dynamic could support ecological conservation goals, but potential impacts to the small communities in which ranches are embedded may be significant if the population of emerging ranchers and smaller operations declines. The feedback between this trend and the specific components of rural community resilience remains an open question.

\section{Trust}

A persistent theme in our interviews revolved around public perceptions of ranchers, land stewardship, the cattle industry, and food production generally. At the core of this issue is the question of trust. Old and young, established and emerging, tended to take issue with a public stereotype that ranchers see land, grass, and cattle as little more than resources of personal economic benefit. Operators in Montana, who are more reliant on public land leases than those in South Dakota and Nebraska, were particularly sensitive to perceived public opinion that characterizes their use of public land as destructive and wasteful. Public land issues aside, many ranchers stressed their dependency on the land, soil, and water: that their relationship with ecological dynamics required diligent attention and care. Many spoke with pride about their grazing rotation systems. Several freely admitted that some ranchers demanded too much of the resources and had done damage over time, but they usually went on to assert that such operators were careless and typically ran themselves out of business such that few were left on the landscape.

The issue of public perception was emphasized most often by emerging ranchers and younger agricultural professionals who were eager to discuss rancher stewardship of environmental resources, the care and consideration given to livestock wellbeing, the biological safety of beef produced in the NGP, the need to develop new or niche beef markets, and the potential for marketing the uniqueness of ranching lifeways to the wider public. On the last two points, one informant said: "The future may be to align your product with a certain breed or maybe your cattle are raised in a certain way. You know, people don't care what it costs if they like the story." He is obviously referring to people within an affluent socioeconomic range, but the larger point is tenable. The rapid growth of organic, fair trade, ethically sourced, and artisanal markets over the past two decades is a

Table 3. Sustainability challenges at lifecycle stages

\begin{tabular}{|l|l|l|l|}
\hline $\begin{array}{l}\text { Increasing } \\
\text { land prices }\end{array}$ & $\begin{array}{l}\text { Emerging }(\boldsymbol{n}=\mathbf{1 3}) \\
\begin{array}{l}\text { Threat: difficult to raise } \\
\text { adequate capital and } \\
\text { impedes profitability }\end{array}\end{array}$ & $\begin{array}{l}\text { Opportunity: increases value of } \\
\text { deeded land, can be used as } \\
\text { leverage }\end{array}$ & $\begin{array}{l}\text { Mixed opportunity \& challenge: } \\
\text { increases value of estate, with } \\
\text { mixed implications }\end{array}$ \\
\hline Agglomeration & $\begin{array}{l}\text { Threat: fewer properties in } \\
\text { available inventory; leads } \\
\text { to loss of local services }\end{array}$ & $\begin{array}{l}\text { Opportunity \& threat: larger properties } \\
\text { can more easily diversify, economies } \\
\text { of scale, but also sensitive to loss of } \\
\text { local services }\end{array}$ & $\begin{array}{l}\text { Mixed opportunity \& challenge: } \\
\text { larger estate to divide means } \\
\text { larger tax burden but possibly } \\
\text { greater assets to distribute }\end{array}$ \\
\hline $\begin{array}{l}\text { Public } \\
\text { perceptions }\end{array}$ & $\begin{array}{l}\text { Opportunity: confident in } \\
\text { using multiple tools to } \\
\text { tell stories and reach } \\
\text { new markets }\end{array}$ & $\begin{array}{l}\text { Threat: less facile in controlling the } \\
\text { narrative, more sensitive to public } \\
\text { lands disputes }\end{array}$ & $\begin{array}{l}\text { Opportunity: multigenerational } \\
\text { longevity as marketing alternative }\end{array}$ \\
\hline
\end{tabular}


testament to the fact that many consumers want to know-and like- - the "stories" of the products they buy. ${ }^{13}$

\section{How Do Sustainability Challenges Vary by Type of Operation?}

Despite relatively homogenous physical and cultural characteristics - high aridity, low annual moisture, extreme temperature variation, low population densities, and economic reliance on agricultural production-striking variations characterize agricultural geographies of the NGP region. Our expectation was that these variations as well as differences in value frameworks of operators would be the key factors distinguishing how operators perceived and experienced sustainability challenges. In this respect, we were informed by the extensive literature in natural resource social science focused on "typologies" of operations - either by size of operation ${ }^{14,15}$ or by measurements of social values. ${ }^{16-19}$

However, after extensive time in the field, it became clear that we needed to move away from values-based typologies given our focus on potential sustainability interventions. From the perspective of what might be done to benefit sustainability of ranch operations in the NGP, the status and age of the operation's current management proved to be a more solid axis of orientation to perceived threats and opportunities. Three relevant stages in an operation's lifecycle emerged from our interviews as distinct phases with respect to sustainability challenges. We define these as emerging, established, and transitioning in Table 2.

While these types are not wholly discrete and there can be crossover between them, they help describe a key aspect of how the variation in dynamics affects the future of ranching in the NGP. Table 3, below, provides an illustration of three key concerns and how they vary at different stages of the ranch ownership lifecycle. For reference, we provide a tally of the number of interviewees in each category in the first row.

\section{What are the Emerging Opportunities for Research, Conservation Strategy and Interventions?}

Based on our research, we see an opportunity to implement a new conceptual framework for NGOs, government agencies, and other conservation partners to assist in vetting strategies and evaluating program outcomes. We suggest orienting strategies focused on ranchers and communities around the lifecycle typology using the networked gears concept shown in Figure 2. We suggest that expanding the diversity across types of ranchers (values, operations, and lifecycles) and creating synergies among them opens up a new way of thinking about conservation strategies.

A set of program evaluation approaches follows from this framework. Specifically, sustainability interventions and programs could be evaluated based on the following questions: Does the program direct capital (human, financial, social) to resilient land uses? Does the program build and strengthen bridges at multiple scales: family, community, region, beyond?
Does the program lead to lasting informal institutions that support a culture of interdependency and stewardship?

\section{Bolstering the Innovation and Capacity of Emerging Ranchers}

This research confirms the direction of existing strategies that seek to secure a foothold for emerging ranchers and suggests a need for expanding these programs. Assisting emerging ranchers, according to this research effort, will demand more than coming up with loan funds, or extra forage. Rather it will mean rethinking the existing pathway that operators follow on the route from emerging to established ranchers. This has implications for ranchers at both ends of the lifecycle. For emerging ranches to achieve and maintain viability, agricultural professionals and operators noted that they have to be willing to diversify, develop multiple enterprises, and create means for operational flexibility. ${ }^{20-22}$

To maintain the diversity of ranch types operating currently in the NGP, transitioning ranchers will likely have to be willing to work creatively with emerging ranchers and smaller operations in order for these communities to maintain their population base. This may mean accepting less for their land than they would otherwise receive on the open market. It might mean forgoing immediate payout from a land sale to give a beginning rancher or a smaller operation the opportunity to have a secure lease.

\section{Characterizing and Addressing Agglomeration Impacts}

The strongest and most pressing consensus on the part of ranchers and local experts about future sustainability challenges in the NGP centers on agglomeration of existing properties into larger units. Future research will be important to expand the empirical knowledge base about the relationship between price trends, ownership patterns, and the viability of local-scale institutions. Engaging in such analysis will have the added benefit of providing an important foundation for monitoring the health of ranching landscapes: accurate descriptions of land ownership patterns based in carefully curated and cleaned cadastral and parcel datasets. This work will complement conservation strategies that target key issues for emerging ranchers, including grass banking; strengthening local leadership capacity; and education and assistance in transition planning, business planning, and marketing. A new approach that is currently missing and that is supported by this research is greater emphasis on the role that nonlocal wealth and ownership patterns can play in augmenting local ranch economiesthrough employment, leasing availability, or other as-yet unidentified creative solutions.

\section{Beyond the NGP}

The goal of this research exercise was to inform conservation practice in the Northern Great Plains, a region of global conservation significance. Still, the relevance of our findings is not limited to this geography. Many of the issues noted in this study such as the impacts of property agglomeration and concerns about the stewardship reputation 

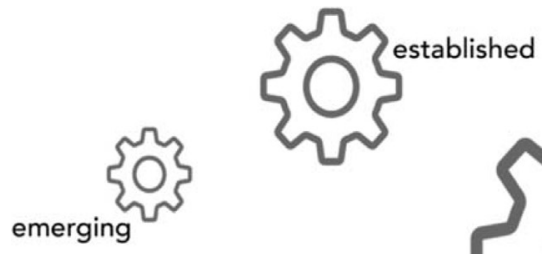

emerging

\section{CURRENT SITUATION}

In the current situation, emerging ranchers are a minority, the group of transitioning ranchers is growing and disproportionately powerful, and entities are often disconnected across life cycles and geographies.

Sustainability interventions could focus on two remedies to this situation, first equalizingin order to create patterns of influence across these groups and more diversity among them.
Here, the logic is that resilient rural communities are an important conservation priority for the NGP region. Resilient rural NGP communities will feature a diverse portfolio with respect to size and status of agricultural operations because diversity - especially the presence of emerging operationscreates opportunities to enhance many of the assets that define resilient communities and responsible land uses: leadership, knowledge, innovation, willingness to embrace change, social networks and opportunities for social learning.

The complementary stage of this approach focuses on connectingacross cohorts of ranches - at family, community and regional scales and across stages of development and rancher values.
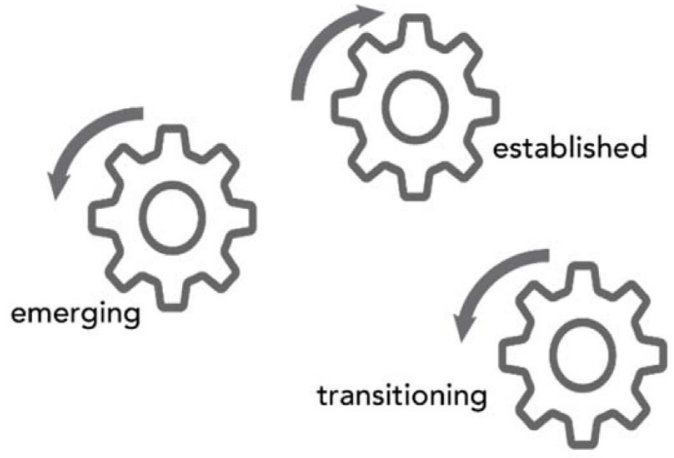

Step 1: Equalize

These connections might be facilitated by a coalition of established ranchers and bridging organizations. Such connectivity is a feature of resilient communities and has the potential to enhance resiliency moving forward. The right architecture of bridging organizations also has the corollary benefit of helping to build trust that ranchers in our study feel is lacking.

Step 2: Connect

Figure 2. Connecting across lifecycles and landscapes.

of ranching are not unique to the region. The rangeland social science community can contribute to a broader understanding of their magnitude and scope through future comparative research and dialogue. In addition, the lifecycle approach highlights the differences in capacities and concerns of rangeland agricultural operators as a function of length of tenure, offering a valuable complement to social science approaches that stratify operations by size or motivation. We submit that using tenure cohorts to assess differential impacts and options on target stakeholders could help agencies and NGOs when developing, implementing and assessing range conservation programs. We are hopeful that the lifecycle will provide common ground for future comparative research as well as collaboration between researchers and managers.

\section{Acknowledgments}

The authors gratefully acknowledge the participants in this research who shared their time and insights generously. We recognize the support of Montana State University's Department of Earth Sciences and Institute on Ecosystems. We are especially grateful to Anne Gage and Jesse Tufte of the World Wildlife Fund for their collaboration in this work. We thank two anonymous reviewers for their helpful feedback.

\section{References}

1. World WiLdLIFe Fund, 2017. Northern Great Plains. Available at: https://www.worldwildlife.org/places/northern-great-plains. Accessed 16 October 2017. 
2. Auger, M., And J.H. Haggerty. 2016. Ranch Management and Ownership Dynamics in the Northern Great Plains. Report to World Wildlife Fund. June 2016. Available at:, https://doi. org/10.6084/m9.figshare.5998433. Accessed 1 November 2017.

3. Hongli, F., D. Hennessy, and R. Miao. 2012. The effects of government payments on cropland acreage, conservation reserve program enrollment, and grassland conversion in the Dakotas. American Journal of Agricultural Economics 95:412-418.

4. Brain, R.G., M.E. Hostetler, and T.A. Irani. 2014. Why do cattle ranchers participate in conservation easement agreements? Key motivators in decision making. Agroecology and Sustainable Food Systems 38:299-316.

5. Brunson, M., and L. Huntsinger. 2008. Ranching as a conservation strategy: can old ranchers save the new West? Rangeland Ecology Eं Management 61:137-147.

6. GRIPNE, S.L. 2005. Grassbanks: bartering for conservation. Rangelands 27:24-28.

7. Kreuter, U.P., D.W. Wolfe, K.B. Hays, and J.R. Conner. 2017. Conservation credits - evolution of a market-oriented approach to recovery of species of concern on private land. Rangeland Ecology and Management 70:264-272.

8. BABBIE, E. 2008. The practice of social research. Belmont, CA, USA: Wadsworth Cengage Learning. Luker, K. 2008. Salsa dancing into the social sciences: research in an age of info-glut. Harvard University Press.

9. Glaser, B.G., And A.L. Strauss. 1967. The discovery of grounded theory: strategies for qualitative research. New York, NY, USA: De Gruyter.

10. Janssen, L., J. Davis, AND S.A. InKoOM. . South Dakota Agricultural Land Market Trends 1991-2015. Report Number 03-7008-2015. Available at: http://openprairie.sdstate.edu/agexperimentsta_circ/335/. Accessed 2 September 2016.

11. Turner, B.L., M. Wuellner, T. Nichols, and R. Gates. 2014. Dueling land ethics: uncovering mental models to better understand recent land use conversion. Journal Agricultural and Environmental Ethics 27:831-856.

12. Lequieu, A. 2015. Keeping the farm in the family name: patrimonial narratives and negotiations among German-heritage farmers. Rural Sociology 80:39-59.

13. Ragas, M.W., and M.S. Roberts. 2009. Communicating corporate social responsibility and brand sincerity: a case study of
Chipotle Mexican Grill's "Food with Integrity" Program. International Journal of Strategic Communication 3:264-280.

14. Haggerty, J. . The Agricultural Economy and Public Lands Ranching Strategies in Southern Utah. Available at: http:// headwaterseconomics.org/land/reports/ranching-southern-utah/.

15. WILMER, H., AND M. FERNÁNDEZ-GIMÉNEZ. 2015. Rethinking rancher decision-making: a grounded theory of ranching approaches to drought and succession management. The Rangeland Journal 37:517-528.

16. Gentner, B., And J.A. Tanaka. 2002. Classifying federal public land grazing permittees. Journal of Range Management 55:2-11.

17. Gosnell, H., J.H. Haggerty, and W.R. Travis. 2006. Ranchland ownership change in the Greater Yellowstone Ecosystem, 1990-2001: implications for conservation. Society and Natural Resources 19:743-758.

18. Mealor, R.D., P.H. Meiman, A.L. Hild, D.T. Taylor, and J.S. THOMPSON. 2014. New rangeland residents in Wyoming? A survey of exurban landowners. Rangeland Ecology $\Xi^{\circ}$ Management 64:479-487.

19. Sorice, M., U.P. Kreuter, B.P. Wilcox, And W.E. Fox. 2014. Changing landowners, changing ecosystem? Land-ownership motivations as drivers of land management change practices. Journal of Environmental Management 133:144-152.

20. Barbieri, C., E. Mahoney, And L. Butler. 2008. Understanding the nature and extent of farm and ranch diversification in North America. Rural Sociology 73:205-229.

21. Inwood, S., AND J. Sharp. 2012. Farm persistence and adaptation at the rural urban interface: succession and farm adjustment. Journal of Rural Studies 28:107-117.

22. Sayre, N., L. Carlise, and L. Huntsinger. 2012. The role of rangelands in diversified farming systems: innovations, obstacles, and opportunities in the USA. Ecology and Society 17:43.

Authors are Resources and Communities Research Group, Department of Earth Sciences, Montana State University, Bozeman, Bozeman, MT 59717-3480, USA (Haggerty, Julia.haggerty@montana.edu); (Auger); and (Epstein). Support for this research was provided by World Wildlife Fund's Sustainable Ranching Initiative. The authors maintained full independence in the production of this work and claim responsibility for any and all errors and content, except where noted. 